\title{
THE ECOLOGICAL INFLUENCE OF LARGE HERBIVORES - BEHAVIOR AND HABITAT UTILIZATION OF CATTLE AND HORSES
}

\author{
Almut POPP $^{1}-$ KLAUS M. SCHEIBE ${ }^{2 *}$ \\ ${ }^{1}$ Am Schäferbruch 13, D- 19243 Wittenburg, Germany \\ (e-mail:almutpopp@yahoo.de) \\ ${ }^{2}$ Institute for Zoo and Wildlife Research \\ PF 601103, D - 10252 Berlin, Germany \\ *Corresponding author \\ e-mail:kscheibe@izw-berlin.de \\ (Received $14^{\text {th }}$ Feb 2012; accepted $22^{\text {nd }}$ July 2014)
}

\begin{abstract}
Heck“ cattle (Bos taurus primigenius, 23 individuals) and Exmoor ponies (Equus ferus caballus, 11 individuals) were introduced in a 171 ha tract of forest and pasture. Time budgets of behavior and habitat preferences were calculated. Horses showed significantly more grazing $(p<0.001)$, standing $(\mathrm{p}<0.01)$ and comfort behavior $(\mathrm{p}<0.05)$ and more lying $(\mathrm{p}<0.001)$ and relocation $(\mathrm{p}<0.001)$ than cattle. The overall preference indices (Chesson index) had positive values at both species in open pastures (cattle 0,42 and horses 0.33 ) and for the edges of the wood $(0.16,0.13)$. The closed wood was avoided by the cattle with -0.51 and horses with -0.57 . The highest preference values based on feces dispersion were +0.84 for the cattle in open pasture and +0.64 for the horses in the alder marsh. Both species showed the highest habitat preferences for feeding in open pastures $(0.81,0.77)$ and for moving in edges of the wooded areas $(0.75,0.69)$. Horses preferred the closed wooded area for resting $(0.17)$. The median of the daily distances walked was larger for cattle than for horses $(\mathrm{p}<0.001)$ but horses reached the larger maximal distance per day (7018 m ) compared to cattle $(6762 \mathrm{~m})$.
\end{abstract}

Keywords: forest, herbivores, nature protection, time budgets, feces, walking distances

\section{Introduction}

Ungulate herbivores and spermatophytes including trees have co-evolved over long periods of time and large herbivores show distinct adaptations to semi-open habitats characterized by sparse woods. The natural vegetation is adapted in many ways to being used as pasture. The former practice of pasturing in woodlands was based on the given natural circumstances. It enabled domesticated animals to perform natural behavior in a close to natural habitat. The domesticated grazers occupied the vacant ecological niches of wild animals that had died out (aurochs, Bos primigenius, European bison Bison bison, moose, Alces alces, and tarpan, Equus ferus) or become rare (red deer, Cervus elaphus ) and played in so far a natural role as long as they were kept in moderate density. Apart from being used as pasture, in the past, the forests have been used very intensively for fire wood, collection of foliage and, in recent times, charcoal until the rising demands of wood could not longer satisfied at the time of early industrialization. Accordingly, between 1850 and 1880 the pasturing rights in Germany were reorganized because of the conflicts between unnatural high grazing pressure of domesticated animals and forestry which led to a separation between forestry and pasturing (Küster 1998). Large areas were reforested and the grazers were restricted to open areas. According to the Forest laws in Germany, it was strictly forbidden to keep domestic animals like cattle and horses in forests. Due to this, the landscape has changed

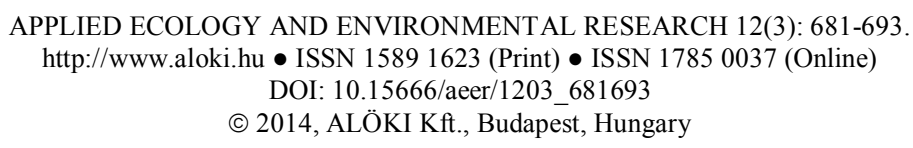


dramatically, and these unnatural forms of husbandry have existed until today. Recent discussions about the aim and practice of nature conservation put in question this separation and discuss the role and function of large herbivores, domestic or wild, for natural development (Riecken et al. 2001). Under certain circumstances, herbivores may favour habitat biodiversity (Zahn et al. 2007) but this depends between mainly on the spatial and nutritional behavior of the animals. Since these species have not been kept under such conditions, scientific analysis of their behavior and ecological function are mainly lacking. Consequently the aim of the study was to analyze the general behavior budgets and the habitat preferences of the two species in closed to natural population densities. It was the question if under such conditions these species would develop a behavior that cause such disturbances of wood development as assumed by most foresters.

We tested the hypothesis, if these species generally prefer the closed wooded areas or prefer the open pasture. A second question was, if these species use the different vegetation units for feeding and resting differently, such as open areas for grazing or woods for resting. In the following the question should be answered, if two herbivore species, a ruminant and a non-ruminant roughage eater, in the same area would act as competitors or as supplementary plant consumers. This would lead to the argument, if single-species or mixed-species projects for nature conservation should be preferred.

\section{Animals, Material and Methods}

\section{Project Area}

As experimental area a tract of 171 ha of forest with shares of open space has been used in the "Weserbergland" region in Lower Saxony. The area included 11ha open range without woods and 160 ha of differing types of wood. Deciduous forests were predominant (127.9 ha) and consisted of oaks (Quercus robur 107.4 ha), beech (Fagus sylvatica), hornbeams (Carpinus betulus) and alder (Alnus glutinosa). Coniferous forests (27.6 ha) consisted of spruce (Picea abies $23.3 \mathrm{ha}$ ), larch (Larix deciduas $4.7 \mathrm{ha}$ ) and some Douglas forests (Pseudotsuga mensiesii, 0.2 ha), alder marsh (1.7 ha), and coppice (1.4 ha).

The herbal layer included Luculo fagaetum Stellario-Carpineten, Pteridium aquilinum and other ferns. The shrubs present were Rubus idaeus, Corylus avellana and Rubus fruticosus. The edges of the wood were defined as an area measuring $5-\mathrm{m}$ from both sides of the boundary between the wood and the open pasture.

The large open pasture of 9 ha was dominated by poaceae and white clover (Trifolium pratensis), and few shrubs like Prunus spinosa, Crataegus laevigata/ monogyna and Sambucus nigra were present beyond the wood. The clearings (1.1 ha) inside the woods were structured like the open pasture. Water $(0.5 \mathrm{ha})$ was present as a brook and a pond. Forest tracks (2.4 ha) and trails of the animals (1.4 ha) pervaded all the project area. During the wintertime a hayrack was furnished.

\section{Animals}

The introduced animals were a herd of 23 adult cows with calves and one bull of the breed Heck cattle and 11 horses of the breed Exmoor pony. The Heck cattle were breed as cattle with a similar morphology of the aurochs but are smaller in size. The Exmoor pony is the oldest and purist of the British native pony breeds and comes from the open 
moors of south western England. The horses were forming two groups which each one stallion. The numbers were stabile during the time of the investigations. All animals could be identified by earmarks, additionally one cow and one mare were equipped with VHF radio-collars. In 2004, both species were observed for 148.25 hours, which resulted in 3025 observation points. In 2005, in total 150 hours with 3085 observations points were recorded for horses and cattle.

\section{Behavior Recording}

The observations of the cattle and horses were conducted during the growing seasons (April to October). Twice a month, observations were made of each herd, and all of them were conducted during daylight hours, from 2 hours after dusk until 2 hours before dawn. Five focus animals were chosen from each herd. The applied method for the observations of behavior was scan sampling (Altmann 1974, Martin and Bateson 1986).

At intervals of 15 minutes the occurrence of the basic behavior patterns (see Table 1) was recorded. The data evaluation was performed with Excel 2000 and SsS 1.0 (GTest). Furthermore, the behavior recordings were used to calculate preference indices in relation to the habitats wood and open pastures for grazing, moving, and resting separately.

Table 1. Definitions of the recorded parameters of behaviour

\begin{tabular}{|c|c|}
\hline Parameters of behaviour & Definitions \\
\hline Grazing & Grazing on grasses and herbs (moving with head down) \\
\hline Browsing & Browsing on twigs, leafs and buds \\
\hline Drinking & Drinking from natural water sites \\
\hline Standing & Standing, doing nothing else \\
\hline Lying & Lying, doing nothing \\
\hline Walking & Slow movement of individual animals without the herd \\
\hline Running & $\begin{array}{l}\text { Fast movement of individual animals with or without the } \\
\text { herd }\end{array}$ \\
\hline Relocation & $\begin{array}{l}\text { Movement of all animals in the herd from one place to } \\
\text { another }\end{array}$ \\
\hline Comfort behaviour & Rubbing against surfaces, grating, licking, wallowing \\
\hline Social behaviour & $\begin{array}{l}\text { Physical interactions between animals (mutual rubbing, } \\
\text { grooming, licking, suckling, pushing, knocking, biting) }\end{array}$ \\
\hline
\end{tabular}

\section{Habitat use}

Records were carried out by direct observation and by collection of feces. For visual location the animals were followed by means of the telemetry device (tracking), and animal positions visually identified with help of a handheld GPS-receiver, a compass, distinctive structures and positioning rods, and marked on a map. For every stay point the position of the central animal of the herd was determined. The feces depositions were located during two systematic screening tours (spring and autumn 2005). The positions were used to calculate habitat preferences independent of the behavior, as well as depending from the basic behaviors (see above). 
The animal positions were analyzed with topographic raster maps (100 by $100 \mathrm{~m})$ and digital maps. All these positions were transformed from the map on GIS Arc-View 3.2. Relative utilization frequencies were computed for the habitat types and tested for equal distribution by the Kolmogorov-Smirnov test (SPSS). Based on the stay frequencies habitat preferences were determined by GIS- procedures. To calculate the habitat preferences, the Chesson Index (Chesson 1978) was applied.

$$
\alpha_{i}=\frac{\frac{r_{i}}{n_{i}}}{\sum_{i=1}^{m} \frac{r_{i}}{n_{i}}}
$$

$r_{i}=$ relative use of the habitats $i, n_{i}=$ relative share of the habitats $i, m=$ maximum of the number of the habitats).

A selective use result in a transgression of $\alpha 1=1 / \mathrm{m}$.

Additionally, preferences were also estimated by mapping faeces with the same mode.

\section{Walking Distances}

The distances covered daily by the herds were computed based on the mapped positions at 15 minute intervals. The positions were linked by straight lines and their length summed up for the observation days. For testing differences of the mean distances per species the U-Test was used, for testing the difference of the absolute distances the G-Test.

\section{Results}

\section{Behavior}

The time budgets for the particular elements of cattle and horse behavior were compared (Table 2). Grazing occupied the greatest amount of time in both species, where the horses grazed significantly more than the cattle $(\mathrm{p}<0.001, \mathrm{G}-\mathrm{Test})$. Grazing

Table 2. The time budgets of the behavioral parameters $\left({ }^{*} p<0.05\right) . n_{\text {cattle }}=6038$ cattle,

$n_{\text {horses }}=6091$

\begin{tabular}{|l|l|l|l|}
\hline Parameters of behavior & Cattle [\%] & Horses [\%] & Significances \\
\hline Grazing & 39.40 & 51.19 & horses $>$ cattle* \\
Browsing & 3.20 & 3.08 & not significant \\
Drinking & 0.40 & 0.60 & not significant \\
Standing & 8.33 & 26.12 & horses $>$ cattle* \\
Lying & 29.61 & 3.73 & cattle $>$ horses* \\
Walking & 2.78 & 2.85 & not significant \\
Running & 0.50 & 1.69 & horses $>$ cattle* \\
Moving (relocation) & 11.63 & 7.72 & cattle $>$ horses* \\
Comfort behavior & 1.23 & 1.67 & horses $>$ cattle* \\
Social behavior & 2.57 & 2.19 & not significant \\
\hline
\end{tabular}


occupied the greatest amount of time in both species, where the horses grazed significantly more than the cattle $(p<0.001, G-T e s t)$. The horses were sometimes observed in a remarkably running behavior, while cattle always walked slowly. However, the cattle changed their positions more frequently than the horses $(p<0.001)$. During the resting periods, the cattle were observed predominantly lying $(p<0.001)$ and the horses standing $(\mathrm{p}<0.001)$. The horses showed a lot more of comfort behavior than the cattle $(\mathrm{p}<0.05)$. Browsing, drinking, walking and social behavior, were not significantly different between both species.

\section{Habtiat use, observed positions}

Most of the times, both animal species were recorded in open pastures (Table 3). The cattle spent a little bit more time in the oak forest than the horses. On the other hand, the horses used the spruce forest more frequently than the cattle. Also, the horses were more frequently in the oak mixed forests than the cattle. The utilization frequencies of the edges of the wooded areas and of the clearings were similar for both animal groups. Comparatively, few observations were made in the larch forest, in the larch-beach forest, and in the coppice. The Douglas forest and the alder marsh habitats had the lowest utilization frequencies. The Chesson - indices confirm the preference for the open pasture and the edges of the wood by both species (Table 3). To a low degree, horses prefer the clearings and the Douglas forest, while cattle prefer to a low degree prefer the coppice.

The Kolmogorov-Smirnov test confirmed that the observed stays were not distributed equally or casually (all the tests with $\mathrm{p}<0.01$ ). Accordingly, the animals used the different habitat structures selectively.

Table 3. Chesson-Index of habitat use by observations. $n=6112$

\begin{tabular}{|c|c|c|c|c|c|}
\hline Habitats & $\begin{array}{l}\% \text { Area of } \\
\text { habitats } \\
\left(\mathrm{n}_{\mathrm{i}}\right) \text { : }\end{array}$ & $\begin{array}{l}\% \text { Use cattle } \\
\text { of habitats } \\
\left(\mathrm{r}_{\mathrm{i}}\right) \text { : } \\
\text { observation } \\
\mathrm{s}\end{array}$ & $\begin{array}{l}\% \text { Use } \\
\text { horses of } \\
\text { habitats }\left(\mathrm{r}_{\mathrm{i}}\right) \\
\text { observation } \\
\mathrm{s}\end{array}$ & $\begin{array}{l}\text { Chesson- } \\
\text { Index }\left(\alpha_{1}\right) \text { : } \\
\text { Cattle } \\
\text { observation } \\
\text { s }\end{array}$ & $\begin{array}{l}\text { Chesson- } \\
\text { Index }\left(\alpha_{1}\right) \text { : } \\
\text { Horses } \\
\text { observation } \\
\mathrm{s}\end{array}$ \\
\hline Open pasture & 5.48 & 52.17 & 42.97 & 0.42 & 0.33 \\
\hline Clearing & 0.63 & 1.33 & 1.64 & 0.09 & 0.11 \\
\hline Edge of the wood & 2.00 & 7.00 & 6.08 & 0.16 & 0.13 \\
\hline Oak forest & 62.04 & 20.58 & 17.17 & 0.01 & 0.01 \\
\hline Oak mixed forest & 10.46 & 3.08 & 7.97 & 0.01 & 0.03 \\
\hline Coppice & 0.78 & 1.75 & 1.07 & 0.10 & 0.06 \\
\hline Alder marsh & 0.98 & 0.92 & 0.96 & 0.04 & 0.04 \\
\hline Larch forest & 2.69 & 2.08 & 2.96 & 0.03 & 0.05 \\
\hline Larch-beech & 133 & 075 & & & \\
\hline Spruce forest & 13.48 & 10.17 & 17.26 & 0.03 & 0.05 \\
\hline Douglas forest & 0.12 & 0.17 & 0.41 & 0.06 & 0.14 \\
\hline
\end{tabular}




\section{Mapped feces}

The feces of the cattle and horses were found in different allotments for the particular habitats. Cattle feces were distributed area-wide. The highest concentrations were found in the open pasture (Table 4). Frequently, cattle feces were located in the spruce forest and the oak forest. The feces of the horses were, in contrast with the cattle feces, concentrated in specific areas. The largest number of feces was found in the oak forest, followed by the spruce forest. However, there were far less horse feces than cattle feces in the open pasture. The parts of the feces of the cattle and the horses, was similar at the edges of the wood, in clearings, in the larch forest, in the alder marsh, in the coppice and in the oak mixed forest. Like the preference indices of the stays, the mapped feces were not distributed equally or casually (tests of Kolmogorov-Smirnov with $\mathrm{p}<0.01$ ), accordingly the rate of utilization of the area was selective.

Table 4. Chesson-Index of habitat use ( $\alpha 1$ ) by faeces. $n=6112$

\begin{tabular}{|l|l|l|l|l|l|}
\hline Habitats & $\begin{array}{l}\text { \%Area of } \\
\text { habitats } \\
\left(\mathrm{n}_{\mathrm{i}}\right):\end{array}$ & $\begin{array}{l}\text { \%Use cattle } \\
\text { of habitats } \\
\left(\mathrm{r}_{\mathrm{i}}\right): \text { faeces }\end{array}$ & $\begin{array}{l}\text { \%Use } \\
\text { horses of } \\
\text { habitats }\left(\mathrm{r}_{\mathrm{i}}\right) \\
\text { faeces }\end{array}$ & $\begin{array}{l}\text { Chesson- } \\
\text { Index }\left(\alpha_{1}\right): \\
\text { Cattle } \\
\text { faeces }\end{array}$ & $\begin{array}{l}\text { Chesson- } \\
\text { Index }\left(\alpha_{1}\right): \\
\text { Horses } \\
\text { faeces }\end{array}$ \\
\hline $\begin{array}{l}\text { Open pasture } \\
\text { Clearing }\end{array}$ & 5.48 & 63.00 & 13.01 & $\mathbf{0 . 6 4}$ & $\mathbf{0 . 1 2}$ \\
Edge of the wood & 0.63 & 0.00 & 0.58 & 0.00 & 0.05 \\
Oak forest & 2.00 & 3.81 & 2.33 & $\mathbf{0 . 1 1}$ & 0.06 \\
Oak mixed forest & 62.04 & 9.87 & 37.09 & 0.01 & 0.03 \\
Coppice & 10.46 & 1.12 & 5.24 & 0.01 & 0.03 \\
Alder marsh & 0.78 & 0.45 & 2.72 & 0.03 & $\mathbf{0 . 1 8}$ \\
Larch forest & 0.98 & 0.45 & 4.47 & 0.03 & $\mathbf{0 . 2 4}$ \\
Larch-beech & 2.69 & 1.57 & 1.17 & 0.03 & 0.02 \\
forest & 1.33 & 1.79 & 3.88 & 0.00 & $\mathbf{0 . 1 5}$ \\
Spruce forest & 13.48 & 17.94 & 29.51 & 0.07 & $\mathbf{0 . 1 1}$ \\
Douglas forest & 0.12 & 0.00 & 0.00 & 0.00 & 0.00 \\
\hline
\end{tabular}

\section{Habitat use depending on behavior}

The cattle preferred the open pasture for all behaviors, especially for feeding $\left(32,9 \%, \alpha_{1}=0,81\right)$ but to a low degree for moving (Table 5). Wood preferred the cattle for any behavior. For moving, the edges were more preferred than the other structures. Horses instead, showed a preference for the wood for resting behavior $\left(26,69 \%, \alpha_{1}\right.$ $=0,17$ ), while these animals preferred the pasture for all other behaviors just like the cattle but to a lower degree for resting. Like cattle, the horses moved most frequently on the edges of the wood.

\section{Distances}

The recorded absolute distances of the cattle were between 1983 and $6539 \mathrm{~m}$ per day and these of the horses between 1642 and $7018 \mathrm{~m}$ per day (Figure 1). The cattle covered larger daily distances than the horses $(\mathrm{p}<0.001, \mathrm{G}$-Test). The values of means do not differ between their means (U-Test). In the beginning of the year, both species walked 
similar and rising distances. From the maximal values in may (horses) and june (cattle), the distances dropped until they reached a minimum in the middle of the year. After this, the values increased something and to the autumn the distances were falling gradually again in both species.

Table 5. Chesson-Index ( $\alpha 1$ ) of feeding (grazing and browsing), resting (standing and lying) and moving (relocation): $n_{\text {cattle }}=5492, n_{\text {horses }}=5526$.

\begin{tabular}{|l|l|l|l|l|l|l|}
\hline Behavior $\left(\mathbf{r}_{\mathbf{i}}\right)$ & \multicolumn{2}{l|l|l|l|}{ Open pasture } & \multicolumn{2}{l|}{ Closed wood } & \multicolumn{2}{l|}{ Edge of the wood } \\
\hline & $\%$ & $\alpha_{1}$ & $\%$ & $\alpha_{1}$ & $\%$ & $\alpha_{1}$ \\
\hline Feeding cattle & 32.90 & $\mathbf{0 . 8 1}$ & 10.38 & 0.02 & 3.37 & $\mathbf{0 . 1 7}$ \\
Feeding horses & 38.96 & $\mathbf{0 . 7 7}$ & 15.27 & 0.02 & 4.99 & $\mathbf{0 . 2 1}$ \\
Resting cattle & 17.77 & $\mathbf{0 . 6 9}$ & 19.54 & 0.05 & 3.26 & $\mathbf{0 . 2 7}$ \\
Resting horses & 3.62 & $\mathbf{0 . 3 8}$ & 26.69 & $\mathbf{0 . 1 7}$ & 2.03 & $\mathbf{0 . 4 5}$ \\
Moving cattle & 1.69 & $\mathbf{0 . 2 0}$ & 8.03 & 0.06 & 3.06 & $\mathbf{0 . 7 5}$ \\
Moving horses & 1.43 & $\mathbf{0 . 2 6}$ & 5.25 & 0.06 & 1.76 & $\mathbf{0 . 6 9}$ \\
\hline
\end{tabular}

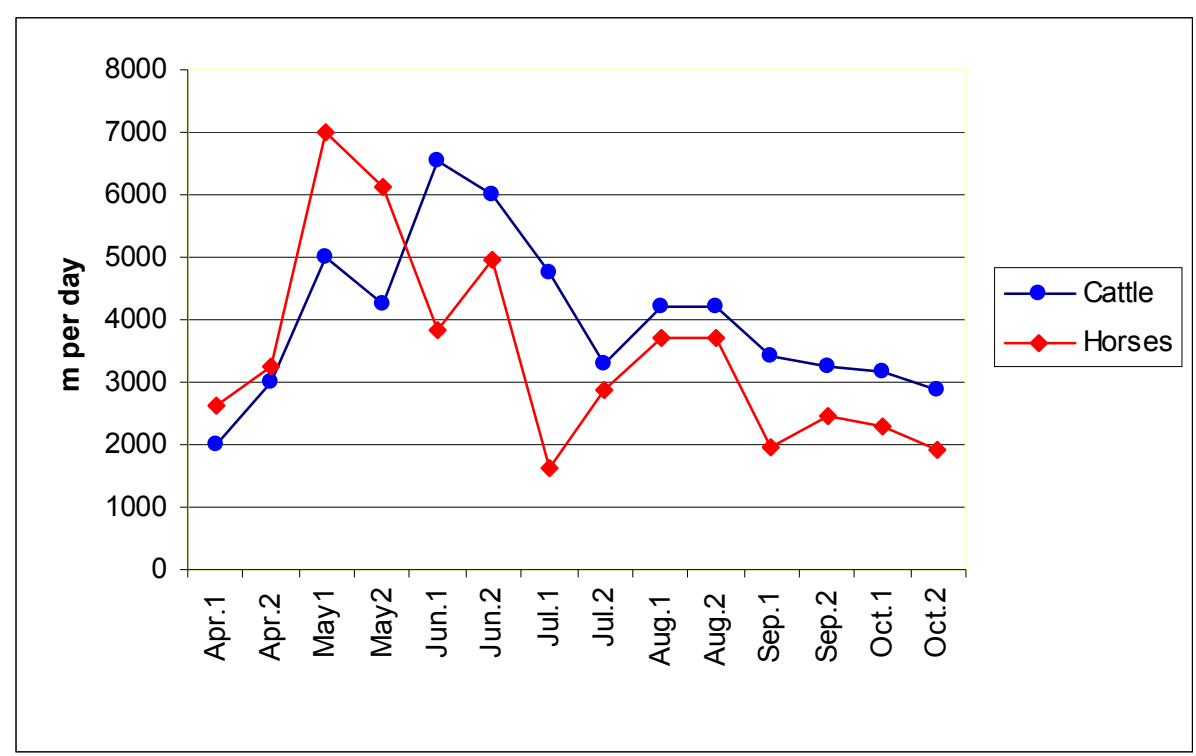

Figure 1. Distances of cattle and horses from April to October, 2 observation days per month.

\section{Discussion}

In central Europe, several projects have been started to reintroduce large herbivores, wild animals such as European bison or feral animals as Konik (Polish feral horses) or Heck Cattle (re-selected primitive breeds) alone or together into close to natural areas. They follow the model of semi-open pastures and "new wilderness" (Riecken et al. 2002, Finck et al. 2004). In this project, the cattle and horses should be investigated for their possible role of wild herbivores.

\section{Reliability of methods}

Like applied method, the scan sampling was used for the stays in the behavioral

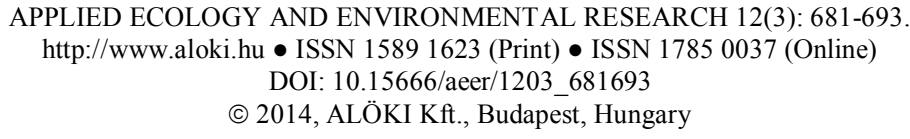


observations and the mapping of the habitat use. It is a current method for investigations into the behavior of cattle, horses and sheep in diverse pasture systems (Hart et al. 1991, Scheibe et al. 1998b). The direct observations resulted in an accurate differentiation of the behavioral elements and should be adopted to study animals in pastures (Jensen et al. 1986). Intervals of 15 minutes were also approved by many other observers ( e.g. Lofgreen et al. (1957), Krysl and Hess (1993, Menhard et al. (2002). The use of time budgets by the behavioral pattern follows other studies (Arnold 1984, Illius et al. 1987, Vulink 2001). The classification of the elements of behavior coincides with those of other authors (Gammon and Roberts 1980, Krysl and Hess 1993, Hepworth et al. 1991). All of them gave the elements grazing, walking, drinking, standing and lying. Resource selection can not alone be evaluated by utilization frequencies. The calculation of the Chesson-Index was recommended as the most convenient index for animal habitat preferences (Manly et al. 1993), and applied frequently (Garshelis 2000, Broglio et al. 2004). Most of the descriptions of cattle and horses refer to observations made during daylight, because the main activities of these animals happened during that time (Arnold and Dudzinski 1978, Zeitler-Feicht 2001). Nevertheless, the lack of nocturnal observations may be a certain disadvantage of this study, which should be overcome by a combination of GPS-telemetry and activity recordings for future investigations (Scheibe et al. 1999).

\section{Behavior results}

Horses are generalist herbivores and coexist with cattle in many ecosystems (Menhard et al. 2002). The percentage of time spent foraging, which consists of grazing, browsing and drinking, was higher in the horses than in the cattle. Our results equal to studies on cattle and ponies in the New Forest (Pratt et al. 1986), the horses spent foraging $75 \%$ of time and the cattle $57 \%$, respectively $60 \%$ (Tubbs 1997). The physiological reason for this is the two animals differing abilities to utilize nutrients (Janis1976). Horses require a higher amount of food compared to cattle to extract the same net energy (Menard et al. 2002). Accordingly, the proportion of the time of browsing in trees and shrubs is also higher in horses than cattle (Pott and Hüppe 1994). The browsing time budgets are very low for both species and coincide with other studies (1\%, Gammon and Roberts 1980, 5\%, Miller and Krueger 1975) . It has been reported that cattle pasturing in wetlands were browsing more than horses, whereas horses grazed for more time (Menhard et al. 2002). The animals spent little time drinking and were drinking irregularly and infrequently. Several authors refer this to the availability of fresh food (Scheibe et al. 1998a, Zeitler-Feicht 2001). Lying during the resting time is an important behavior especially for the cattle (Metz 1985), while horses are able to rest standing with nearly no energy consumption (Budras and Röck 1997). Accordingly, the horses in our study were observed more often standing than lying. The alternation of the resting time in the horses was more irregular than in the cattle. The proportion of time the horses spent running was much higher than in the cattle and is ascribable to social discrepancies between the stallions. Also during the change of places the horses ran more than the cattle. Walking individually, independent of the group, was seldom observed in both species. For the most part it was only observed when the animals were grazing or locating water or resting sites. Cattle changed their positions significantly more frequently than of the horses. The cattle moved away across large distances and for long time, mostly in the morning. They used wooded areas only for short times for foraging. Semi-wild living cattle in the New Forest offer a value of

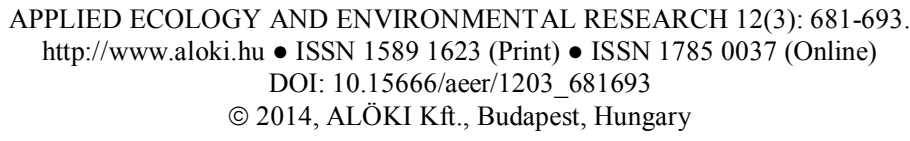


$21 \%$ movement time (Tubbs 1997). Occasions of social and comfort behavior could only be scarcely documented for both species. Comfort behavior was observed significantly more in the horses, where wallowing was a common activity.

\section{Habiat Use Results}

The project area comprised of a wide spectrum of different vegetation and soil and was used by the animals with variable intensity. During all the observation time, the cattle and horses used mostly the open pasture. The same preferences of the open pastures by cattle and horses has been found in the New Forest (Putman et al. 1987). The animals in our investigation used open areas for $70-80 \%$ for foraging. These results are in accordance with the classification of cattle and horses as grazers (Hofmann 1989). Other free living grazing animals such as bison, wildebeest, zebra, antelope and reindeer live in very large herds and migrate across the open and semi-open areas with sufficient aliments and high visibility (Homewood et al. 2001; Lushchekina and Struchkov 2001; Howall 2002; Musiega and Kadazi 2004). In both cases, observations and feces, the cattle and the horses obvious selected the open pasture and in the edges of the wood. Selection of the coppice was identified per observation only. The deciduous woodland covered very large areas of the study area. It was used by both cattle and horses in equal measure. But the cattle crossed wide parts of the woods and stopped for foraging in clearings consisting of raspberries, grasses and herbs. Their favored resting sites were clear of trees and with little vegetation. In contrast, the horses rested in certain sites within the deciduous forests for longer periods of time. The cattle in the New Forest used woodland less, at 10-20\% of their total time (Putman et al. 1987), just as the cattle of our project area avoided the woodland compared to the open pasture. The horses in New Forest showed differences in foraging behavior as did the horses in our project area. Browsing behavior predominated during the wintertime because snow covered the ground vegetation. Both of herds, the cattle and horses, frequented the coniferous woodland to shelter from hot and cold weather, insects and heavy rain. This is a common sheltering behavior in large herbivores (Hancock 1953, Sambraus 1978). The edges of the woods and the clearings were often occupied by both animal groups for foraging or resting and were preferred compared with the other habitats. The places assured shelter from the weather and offered a free view of the open land as well as a short distance to the feeding grounds.

The described behavior strategies indicate that both, cattle and horses originally are adapted to semi-open pastures (Beutler 1996, Bunzel-Drüke 1997). An obvious difference between the species was that the clearings within the forest were much less used by the cattle, as indicated by only a few stays and feces. Cattle always depose their feces in places where they are resting, whereas horses have certain sites for the deposition of their feces (Zeitler-Feicht 2001). These sites of aggregation serve as an olfactory marking of their territory. Only the stallions exhibited a distinctive marking behavior. Both the observed stays and the mapped feces did not demonstrate a stochastic distribution in the cattle or the horses. As a result, the unequal distribution follows the preferred areas, the herd structure and the social behavior (Tyler 1972, Arnold and Dudzinski 1978, Putman et al. 1991). Accumulations of feces can be regarded as an indicator for resting places, because they often were deposited after the resting time (Altmann 1988).

The results of habitat use depending on behavior show similar patterns as independent behavior. Both species preferred very clearly for feeding the open pasture

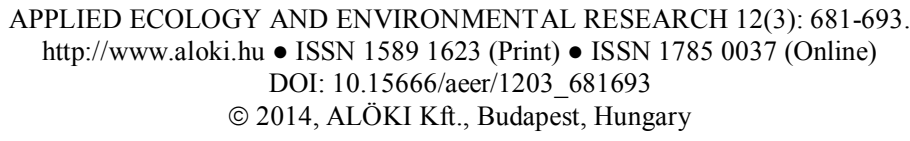


and avoid the closed wood areas. Nevertheless, certain differences became obvious. Horses significantly preferred open pastures and woodland for resting. Movements occurred especially frequently at the edges of the wooded areas in both species while the preference indices for the open pasture where the lowest of all behaviors on the open pasture. Occasional use of edges of the wood like successive mosaic areas offer optimal habitats by food resources better than the wood and by shelter conditions better than the open pastures (Bokdam et al. 2003). Possibly, the edges of the wood serve like orientation. The results support clearly the evolutionary adaptation of these two species for feeding on open areas and demonstrate that they will not suppress the wood development so completely as often assumed.

\section{Distances covered results}

The daily movements of the animals were reflected in their covered distances. The distances were impacted by different factors like the availability of space, nutrients, distance from water, temperature, wind, the age of animals, pregnancy, stocking rate and pasture practices (Anderson and Kothman 1980; Phillips 1993; Karsli 1995). In contrast to the horses, the cattle covered larger distances. It is assumed that the horses, by reason of their smaller groups, require less space and therefore do not need to change their location as often as the cattle. Both animal groups moved further in the spring and the autumn than in the summer. This is possible because of exploration behavior during foraging (Krysl and Hess 1993). In the spring all the vegetation is not available and in the autumn there is a decline of the energy and crude fiber in the food, and the animals have to change their foraging sites more frequently An increase of locomotion could also result, from warm, wet or very windy weather and an over-abundance of insects (Hancock 1953, Phillips 1993, Waite et al. 1951).

\section{Suggestions}

The hypothesis is supported that the two herbivore species generally prefer the open pasture and will not destroy the forest or suppress any tree regeneration if they have a possibility to choose their positions according to their natural preferences and live in moderate population densities. A forest destruction as observed during pasturing before 1850 must not be afraid under these preconditions. Although these species share basically the same habitat structures they differ slightly in their preferences. Furthermore, they differ significantly in ecological relevant behavior elements such as locomotion, resting, or defecation behavior. Accordingly, single species grazing projects will not come close to natural herbivore-habitat interactions. These results support the theory both of additive and complementary utilization of nutrients in free nature by a complex herbivore community also in Central European biotopes. We argue for natureprotection projects in semi-open landscapes including forest with at least two different species such as horses and ruminant species.

Acknowledgements. This publication is a result of the project Conservation of the "Hutelandschaft" and species conservation with large grazers in the nature park "Solling-Vogler" (Lower Saxony, Germany). It was conducted by the University of Applied Sciences Lippe and Höxter, Institute for Animal Ecology in cooperation with the nature park „Solling-Vogler“, Lower Saxony. We acknowledge for the financement the German Federal Agency for Nature Conservation and the Lower Saxony Ministry for Nutrition, Agriculture and Forestry, the Lower Saxony Ministry for Environment, Bingo-Lotto, and Leader+. 


\section{REFERENCES}

[1] Altmann, D. (1988): Harnen und Koten bei Säugetieren. Ziemsen Verlag, Wittenberg.

[2] Altmann, J. (1974): Observational study of behaviours: Sampling methods. - Behaviour 49: 227-267.

[3] Anderson, D.M., Kothmann, M.M. (1980): Relationship of distance traveled with diet and weather for Hereford Heifers. - Journal of Range Management 33: 217-220.

[4] Arnold, G.W. (1984): Comparison of the time budgets and circadian patterns of maintenance activities in sheep, cattle and horses grouped together. - Applied Animal Behaviour Science 13: 19-30.

[5] Arnold, G.W., Dudzinski, M.L. (1978): Ethology of Free-Ranging Domestic Animals. Elsevier Scientific Publications, New York

[6] Beutler, A. (1996): Die Großtierfauna Europas und ihr Einfluss auf Vegetation und Landschaft. - Natur- und Kulturlandschaft 1: 51-106.

[7] Bokdam, J., Gleichman, J.M., van Wieren, S.E., de Vrie,s M.F.W. (2003): Free-ranging cattle as opportunistic exploiters of a successional woodland-grassland-heathland mosaic. In: Bokdam, J. Nature conservation and grazing management. PhD thesis. Ponsen \& Looyen b.v., Wageningen.

[8] Broglio, E., Saiz, E., Calbet, A., Trepat, I., Alcaraz, M. (2004): Trophic impact and prey selection by crustacean zooplankton on the microbial communities of an oligotrophic coastal area (NW Mediterranean Sea). - Aquatic Microbiology and Ecology 35: 65-78.

[9] Budras, K.D., Röck, S. (1997) : Atlas der Anatomie des Pferdes. Schlütersche GmBH, Hannover

[10] Bunzel-Drüke, M. (1997): Klima oder Übernutzung - Wodurch starben Großtiere am Ende des Eiszeitalters aus? - Natur- und Kulturlandschaft 2: 152-193.

[11] Chesson, J. (1978): Measuring preference in selective predation. - Ecology 59: 211-215.

[12] Finck, P., Härdtle, W., Redecker, B., Riecken, U. (2004): Weidelandschaften und Wildnisgebiete - Vom Experiment zur Praxis. - Schriftenreihe Landschaftspflege und Naturschutz 78: 540.

[13] Gammon, D.M., Roberts, B.R. (1980): Grazing Behaviour of cattle during continuous and rotational grazing of the Matopos sandveld of Zimbabwe. - Zimbabwe Journal of Agricultural Research 18: 13-27.

[14] Garshelis, D.L. (2000): Delusions in habitat selection: measuring use, selection, and importance. In: Research techniques in animal ecology. (eds. Boitani L, Fuller TK), Columbia Press, New York

[15] Hancock, J. (1953): Grazing Behaviour of cattle. - Animal breeding abstracts 21: 1-13.

[16] Hart, R.H., Hepworth, K.W., Smith, M.A., Waggoner Jr., J.W. (1991): Cattle grazing behaviour on a foothill elk winter range in southeastern Wyoming. - Journal of Range Management 44: 262-266.

[17] Hepworth, K.W., Test, P.S., Hart, R.H., Waggoner Jr., J.W., Smith, M.A. (1991): Grazing systems, stocking rates, and cattle behaviour in southeastern Wyoming. - Journal of Range Management 44: 259-262.

[18] Hofmann, R.R. (1989): Evolutionary steps of ecophysiological adaptation and diversification of ruminants: a comparative view of their digestive system. - Oecologia. 78: 443-457.

[19] Homewood, K., Lambin, E.F., Coast, E., Kariuki, A., Kikula, I., Kivelia, J., Said, M., Serneels, S., Thompson, M. (2001): Long-term changes in Serengeti-Mara wildebeest and land cover: pastoralism, population, or policies? - PNAS (Proceedings of the National Academy of Sciences of the United States of America) 98: 12544-12549.

[20] Howall, J. (2002): Lessons from nature's migratory herbivores. - Land \& Livestock in Practice 83:12-15.

[21] Illius, A.W., Wood-Gush, D.G.M., Eddison, J.C. (1987): A study of the foraging behaviour of cattle grazing patchy swards. - Biology of Behaviour 12: 33-44.

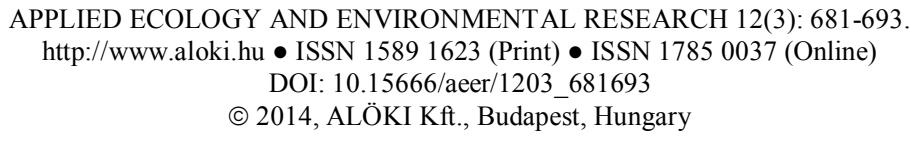


[22] Janis, C. (1976): The evolutionary strategy of the equidae and the origins of rumen and cecal digestion. - Evolution 30: 757-774.

[23] Jensen, P., Algers, B., Ekesbo, I. (1986): Methods of sampling and analysis of data in farm animal ethology. Animal management, Vol. 17. Birkhäuser Verlag, Basel.

[24] Karsli, M.A. (1995): Grazing behaviour of ruminant livestock. In: Harmoney, K.R. Grazing: Forage and animal management. - Agronomy 534 class project.

[25] Krysl, L.J., Hess, B.W. (1993): Influence of supplementation on behaviour of grazing cattle. - Journal of Animal Science 71: 2546-2555.

[26] Küster, H. (1998): Die Geschichte des Waldes von der Urzeit bis zur Gegenwart. Verlag C. H. Beck, München

[27] Lofgreen, G.P., Meyer, J.H., Hull, .JL. (1957): Behaviour patterns of sheep and cattle being fed pasture or soilage. - Journal of Animal Science 16: 766-772.

[28] Lushchekina, A., Struchkov, A. (2001): The Saiga antelope in Europe: once again on the brink? - The Open Country 3: 11-24.

[29] Manly, B., McDonald, L., Thomas, D. (2002): Resource selection by animals. Statistical design and analysis for field studies. Second edition. Kluwer Academic Publishers, Dordrecht

[30] Martin, P., Bateson, P. (1986): Measuring behaviour. Cambridge University Press, Cambridge

[31] Menard, C., Duncan, P., Fleurance, G., Georges, J.Y., Lila, M. (2002): Comparative foraging and nutrition of horses and cattle in European wetlands. - Journal of Applied Ecology. 39: 120-133.

[32] Miller, R.F., Krueger, W.C. (1975): Cattle use on summer foothill rangelands in Northeastern Oregon. - Journal of Range Management 29: 367-371.

[33] Musiega, D.E., Kazadi, S.N. (2004): Simulatine the East African wildebeest migration patterns using GIS and remote sensing. - African Journal of Ecology 42: 355-362.

[34] Phillips, C.J.C. (1993): Cattle behaviour. Farming Press Books, Ipswich

[35] Pott, R., Hüppe, J. (1994): Weidetiere im Naturschutz. Bedeutung der Extensivbeweidung für die Pflege und Erhaltung nordwestdeutscher Hudelandschaften. - LÖBF-Mitteilungen 3: 10-16.

[36] Pratt, R.M., Putman, R.J., Ekins, J.R., Edwards, P.J. (1986): Use of habitat by freeranging cattle and ponies in the new forest, southern England. - Journal of Applied Ecology 23: 539-557.

[37] Putman, R.J., Fowler, A.D., Tout, S. (1991): Patterns of use of ancient grassland by cattle and horses and effects on vegetational composition and structure. - Biological Conservation 56: 329-347.

[38] Putman, R.J., Pratt, R.M., Ekins, J.R., Edwards, P.J. (1987): Food and feeding behaviour of cattle and ponies in the New Forest. - Journal of Applied Ecology 24: 369-380.

[39] Riecken, U., Finck, P., Schröder, E. (2001): Tagungsbericht zum Workshop „Großflächige halboffene Weidesysteme als Alternative zu traditionellen Formen der Landschaftspflege“ - Natur und Landschaft 76: 125-130.

[40] Sambraus, H.H. (1978): Spezielle Ethologie: Rind. In: Sambraus, H.H. (ed.) Nutztierethologie: Das Verhalten landwirtschaftlicher Nutztiere., Verlag Paul Parey, Berlin.

[41] Scheibe, K.M., Eichhorn, K., Kalz, B., Streich, W.J., Scheibe, A. (1998a): Water consumption and watering behaviour of Przewalski horse (Equus ferus przewalskii) in a Semireserve. - Zoo Biology 17: 181-192.

[42] Scheibe, K.M., Eichhorn, K., Schleusener, T., Streich, W.J. (1999): Chronobiological analysis of animal locations - development of an automatic recording system and principles of data processing. 15th. International Symposium on Biotelemetry, May 9-14, 1999, Juneau, Alaska. In: Eiler, J.H., Alcorn, D.J., Neuman, M.R. (eds.) Biotelemetry 15, Wageningen. 398-407. 
[43] Scheibe, K.M., Lange, B., Sieling, C., Scheibe, A. (1998b): Przewalskipferde in einem Semireservat - Entwicklung von Ortspräferenzen und Einfluss auf Vegetationsstrukturen. - Natur- und Kulturlandschaft 3: 348-353.

[44] Tubbs, C.R. (1997): The ecology of postoralism in the New Forest. - British Wildlife 9: 7-16.

[45] Tyler, S.J. (1972): The behaviour and social organization of the New Forest ponies. Animal Behaviour 29: 283-288.

[46] Vulink, J.T. (2001): Hungry herds. Management of temperate lowland wetlands by grazing. Doctoral thesis, Rijks University, Groningen.

[47] Waite, R., MacDonald, W.B., Holmes, W. (1951): Studies in grazing management. III. The behaviour of dairy cows grazes under the clos-folding and rotational systems of management. - Journal of Agricultural Science 41: 163-173.

[48] Zahn, A. , Juen, A., Traugott, M., Lang, A.: Low density cattle grazing enhances arthropod diversity of abandoned wetland. - Applied Ecology and Environmental Research 5: 73-86

[49] Zeitler-Feicht, M.H. (2001): Handbuch Pferdeverhalten. Ursachen, Therapie und Prophylaxe von Problemverhalten. Verlag Eugen Ulmer, Stuttgart. 